Environment Conservation Journal 20 (1\&2) 63-66, 2019

ISSN 0972-3099 (Print) 2278-5124 (Online)

Abstracted and Indexed

\title{
Spiders of Katepurna sanctuary from the family Salticidae (Blackwall, 1841)
}

\author{
Shirbhate Milind V. ${ }^{1}$ and Shirbhate Amrita M. ${ }^{2}$
}

Received: 29.07 .2018

Revised: 28.10.2018

Accepted: 14.02.2019

\begin{abstract}
A detail survey of spiders from Salticidae family was carried out in Katepurna Sanctuary near Akola (Maharashtra). We have reported 20 species from 07 different genera. The maximum species diversity was noted from August 2015 to February, 2018.
\end{abstract}

Key words: Spiders, Katepurna, Salticidae.

\section{Introduction}

Jumping spiders are easily distinguished from other spiders by their four big eyes on the face and four smaller eyes on top of the head. There are around more than 5000 species jumping spiders in the world. These are small to large arenomorph spiders: two tarsal claws: ecribellate: rntelegyne: eight eyes: carapace square fronted with four, forwardly directed eyes of which the anterior median eyes are very large (Coddington, 1991). The adults not making snare-webs; actively pursuing their prey on walls, ground vegetation and foliage, leaping onto their prey in characteristic fashion (Coddington, 1996; Gajbe, 1995a; Gajbe, 1995b; Koh, 2000).

\section{Material and Methods}

Study Area: The Katepurna Sanctuary Akola, Maharashtra is an exotic sanctuary, dotted with an abundance of flora and fauna geographically located at $-20^{\circ} 25^{\prime} 0.54^{\prime \prime} \mathrm{N} 77^{\circ} 10^{\prime} 50.14 " \mathrm{E}$. The land vegetation is southern tropical dry deciduous forest. There are over 115 species of plants at this sanctuary etc. Katepurna Wildlife Sanctuary is renowned for the migratory birds, four-horned antelope and barking deer. Other animals include Black buck, Leopard, Wolf, Wild boar, Hyena, Hare, Nilgai, Jungle cat and Monkeys and other species. The Katepurna water reservoir is a site formany water birds. The salticids were captured in Author's Address

${ }^{1}$ Shankarlal Khandelwal Arts, Science and Commerce College, Akola, India-444002

${ }^{2}$ Mahatma Phule Arts and Science College, Patur Dist. Akola 444501

E-mail.: milindshirbhate2912@gmail.com the bottles by Visual search, Sweeping, Beating, Pitfall trapping and Litter sampling methods. After collecting they were photographed with the help of Macro Lens- camera Canon 60D, in case of small spiders stereo-zoom binocular microscope used (Kunter and Sereg, 2002; Platnick, 2011).

Preservation: Collected specimens were preserved in a separate vial in $70 \%$ alcohol if necessary for the observations of pedipalp and epigyne structures. Identification: Identification was carried out on the basis of morphometric characters of various body parts. The help was mainly taken from the keys and catalogues provided by Tikader (1982), Platnick (2011), and other relevant literature. Juveniles and some immature specimens could not be identified up to species level (Taylor, 1999 and Tikader, 1973a; Tikader, 1973b).

\section{Results and Discussion}

Morphology: The adult spiders $2-10 \mathrm{~mm}$ long; of medium build, plump-bodied; decidedly shortlegged with eight eyes. The eyes eight: in three or four rows; eyes occupying entire width of carapace; anterior median eyes very large; anterior lateral eyes slightly smaller, both pairs directed forward; other eyes directed to the sides or backward. Legs: two claws usually with claw tufts, anterior pair in some genera longer or stronger than other legs, frequently decorated with tufts of setae. Female palp: tarsus without claw. Abdomen: variable, short to oblong or elongated. Spinnerets: short, anterior and posterior pairs, similar in length; without cylindrical glands and spigots. Respiratory System: 
two booklungs; tracheal spiracle close to spinnerets were observed to confirm the genus upto species level (Shirbhate and Shirbhate, 2017).

A detail survey of spiders from salticidae family was carried out in Katepurna Sanctuary during 2018. We have reported 21 species from 7 genera. The maximum species diversity was noted from August to January. Among the collected species 10 are males and 11 are females.

Table-1: Spider genera and species of family Salticidae from Katepurna Sanctuary Akola (Maharashtra, India) during 2015-2016.

\begin{tabular}{|l|l|l|}
\hline SN & Genus & Number of species \\
\hline $\mathbf{1}$ & Marpissa & 07 \\
\hline $\mathbf{2}$ & Rhene & 03 \\
\hline $\mathbf{3}$ & Euophrys & 01 \\
\hline $\mathbf{4}$ & Myrmarachne & 02 \\
\hline $\mathbf{5}$ & Phidippus & 04 \\
\hline $\mathbf{6}$ & Telomonia & 02 \\
\hline $\mathbf{7}$ & Plexippus & 02 \\
\hline
\end{tabular}

Thus Katepurna Sanctuary is having a good salticid spider diversity. Marpissa is represented by 7 species followed by Phidippus 4 and Rhene 3. Results are compared. Thus the Katepurna Sanctuary is having rich diversity of Salticid Jumping spiders as these spiders are very useful to maintain the ecological balance. If the spiders will conserve ultimately it helps the prey predator chain in the sanctuary area (Tikader, 1987 and Tikader, 1982).

\section{Acknowledgements}

Authors are very much thankful to University Grants Commission New Delhi \& WRO- Pune for providing the research grants. Also thankful to Conservator of Forests and Field Director, Melghat Tiger Project, Amravati. Office \& Field staff of the Katepurna Wildlife Sanctuary, Akola and Maharashtra State Biodiversity Board, Nagpur for permission to do this work on spiders also thankful to all the members of Nisargakatta team Akola. to all the members of Nisargakatta team Akola.

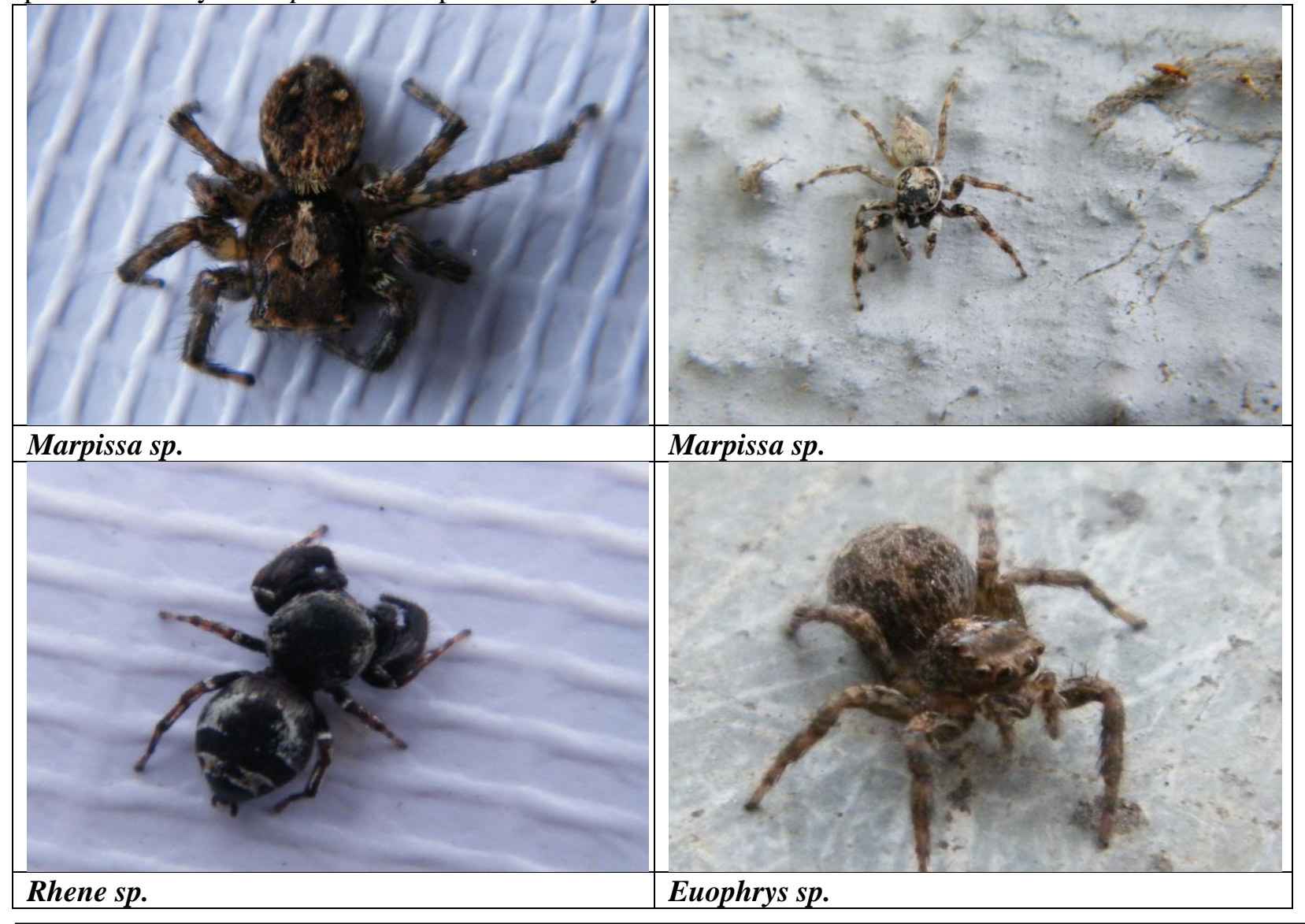




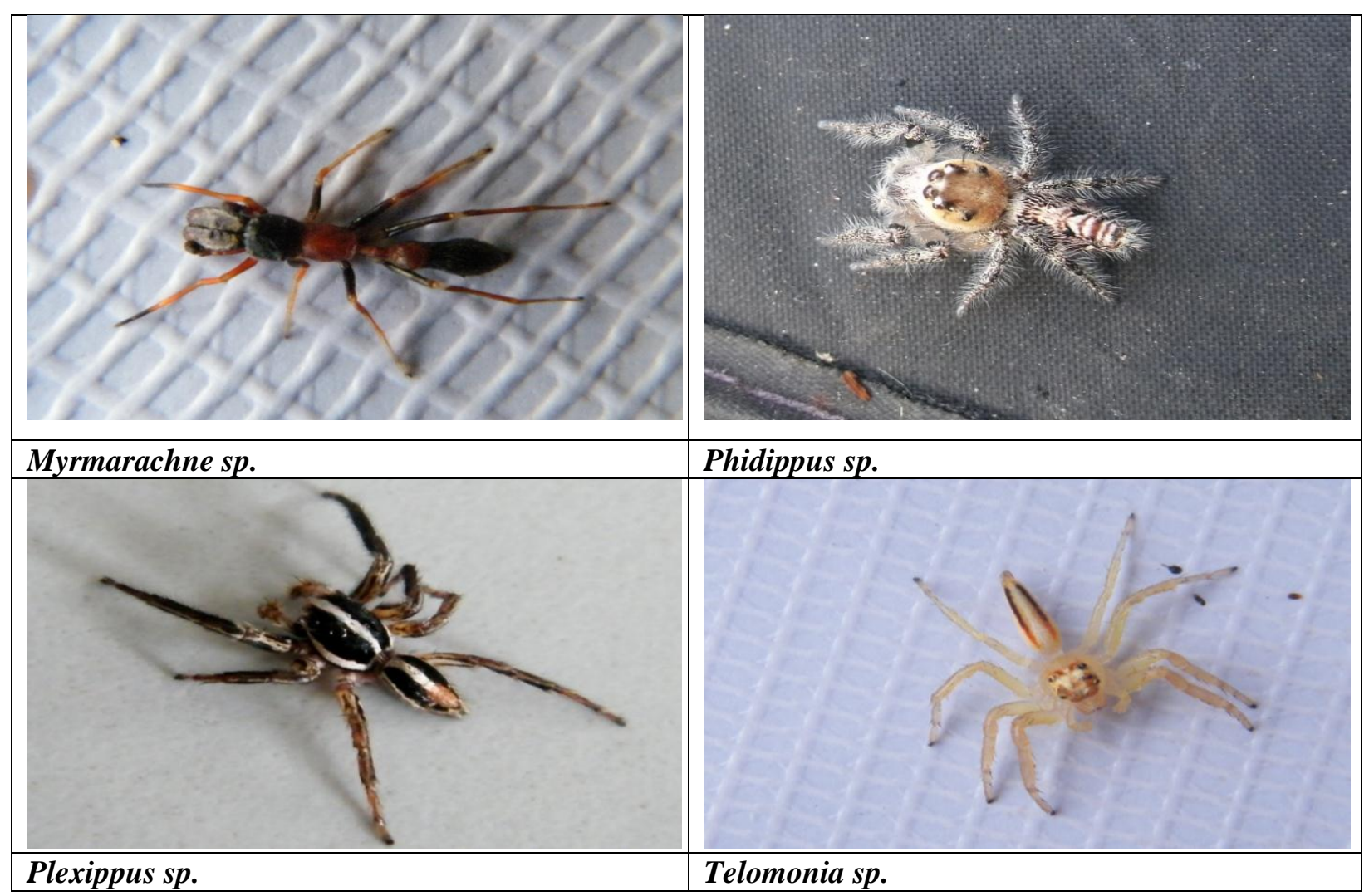

Fig 1. Photograph showing the generic diversity of family Salticidae from Katepurna Sanctuary, Akola (Maharashtra, India).

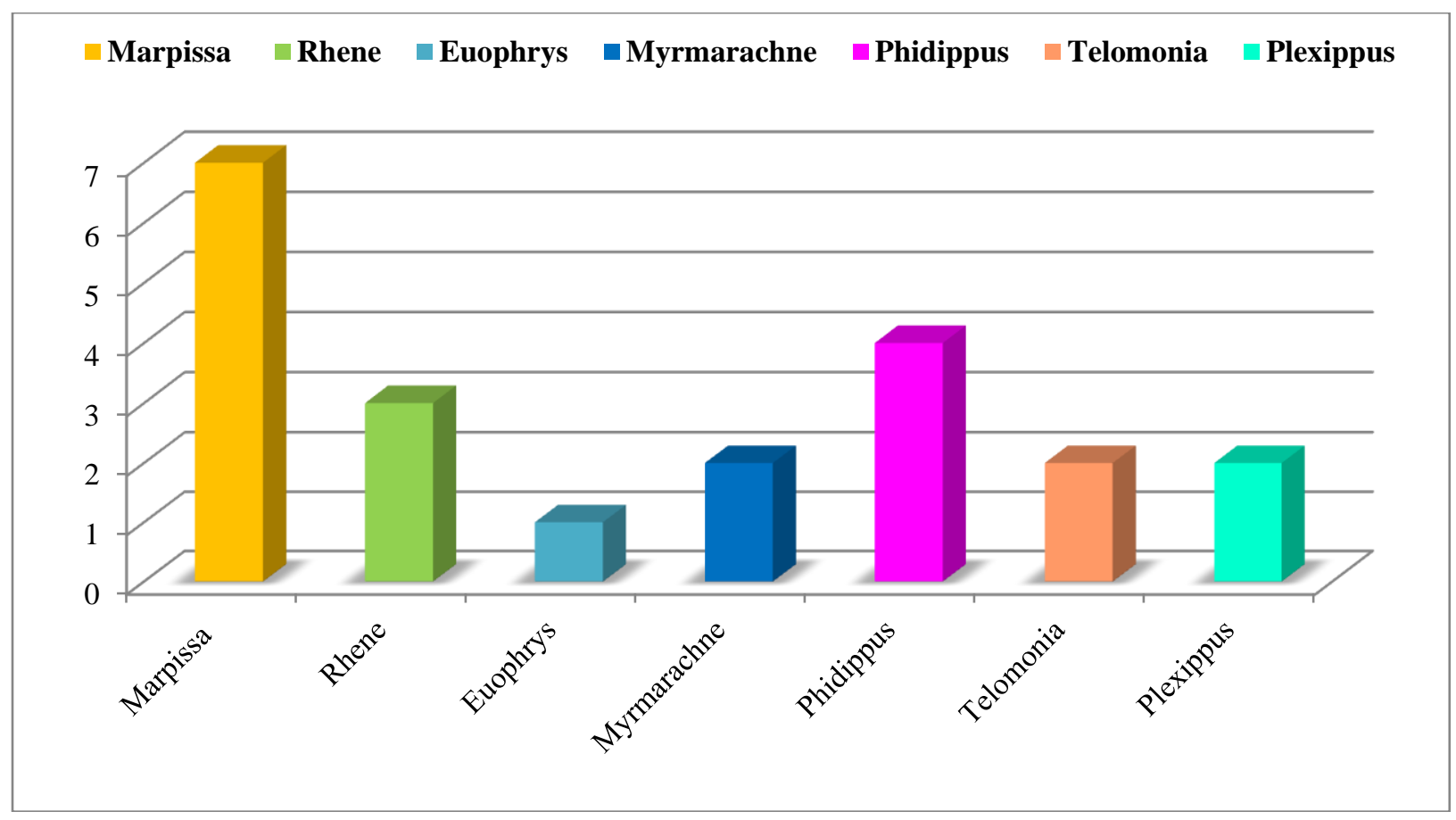

Fig. 2- Generic Diversity of Family Salticidae in Katepurna Sanctuary Akola, India 


\section{Shirbhate and Shirbhate}

\section{References}

Coddington, J. A. and Levi, H. W. 1991. Systematics and evolution of spiders (Araneae). Annual Review of Ecology and Systematics, 22: 565-592.

Coddington, J. A., L. H. Young and Coyle, F. A. 1996. Estimating spider species richness in a southern Appalachian Cove hardwood forest. Journal of Arachnology, 24: 111-128.

Gajbe, U. A. 1995a. Spider Fauna of Conservation Areas: Fauna of Indravati Tiger Reserve, Madhya Pradesh. Zoological Survey of India, publication: 53-56.

Gajbe, U. A. 1995b. Spider Fauna of Conservation Areas: Fauna of Kanha Tiger Reserve, Madhya Pradesh. Zoological survey of India, publication: 27-30.

Koh, J. K. H. 2000. A Guide to Common Singapore Spiders Singapore Science Centre, Singapore. 160.

Kuntner, M. and Sereg, I. 2002. Additions to the spider fauna of Slovenia, with a comparison of spider species richness among European countries. Bulletin of the British Arachnological Society, 12:185-195.
Platnick, N. 2011. The World Spider Catalog, Version 11.5 American Museum of Natural History, online at http://research.amnh.org/entomology/spiders/catalog8187/index.html.

Shirbhate Milind V. and Shirbhate Amrita M. 2017. Diversity and distribution of Spider fauna (family- Araneidae) in and around Katepurna Sanctuary, Akola, India. Environment Conservation Journal, 18(3): 45-52.

Taylor B. 1999. Ed. Spiders, Lorenz Books, New York. 64.

Tikader, B. K. 1973a. Studies on some Ant like spiders from India (Family: Salticidae), 78(2): 59-67.

Tikader, B. K. 1973b. Studies on some jumping spiders from India (Family-Salticidae), 78(2): 68-72.

Tikader, B. K. 1987. Handbook of Indian Spiders, Zoological Survey of India, Calcutta, India. 251.

Tikader, B. K. 1982. The Fauna of Indian Spiders Araneae (Araneidae and Gnaphosidae). Zological Survey of India, Calcutta. 536. 